\title{
Pulmonary Artery Branch
}

National Cancer Institute

\section{Source}

National Cancer Institute. Pulmonary Artery Branch. NCI Thesaurus. Code C33427.

Any artery arising from the pulmonary artery. 